\title{
East African cassava mosaic virus-Uganda (EACMV-UG) and African cassava mosaic virus (ACMV) reported for the first time in Central African Republic and Chad
}

\author{
I. Zinga ${ }^{1,2}$, M. Harimalala ${ }^{1}$, A. De Bruyn ${ }^{1}$, M. Hoareau ${ }^{1}$, N. Mandakombo ${ }^{2}$, S. Semballa ${ }^{2}$, B. Reynaud ${ }^{1}$, P. Lefeuvre ${ }^{1}$ and \\ J.M. Lett ${ }^{2 *}$ \\ ${ }^{1}$ Laboratoire des Sciences Biologiques et Agronomiques pour le Développement (LSBAD), Université de Bangui, BP908 \\ Bangui, Centrafrique; ${ }^{2}$ CIRAD, UMR PVBMT, Pôle de Protection des Plantes, 7 Chemin de I'IRAT, 97410 Saint Pierre, La \\ Réunion, France
}

*E-mail: lett@cirad.fr

Received: 25 May 2012. Published: 05 Nov 2012. Keywords: cassava mosaic disease, cassava mosaic geminiviruses (CMGs), Manihot esculenta, Uganda variant

Cassava (Manihot esculenta) is a major staple food crop cultivated throughout Africa. It is affected most severely by cassava mosaic disease (CMD) at high incidence wherever it is grown on the continent. The disease may be caused by seven cassava mosaic geminiviruses (CMGs) belonging to the genus Begomovirus (family Geminiviridae; Patil et al., 2009). In Uganda, an extremely severe epidemic of CMD has developed since the 1990s, and is supposed to have progressed since then in neighbouring countries and Central Africa. The severe CMD phenotype is caused by the synergistic interaction between African cassava mosaic virus (ACMV) and a distinct recombinant strain of East African cassava mosaic virus (EACMV-UG), commonly known as the "Uganda variant". EACMV-UG was described recently in countries bordering the Central African Republic (CAR) and Chad: the Congo Republic and the Democratic Republic of Congo (Neuenschwander et al., 2002), Sudan (Tadu et al., 2005) and Cameroon (Akinbade et al., 2010). CMD is reported to be widespread in CAR (Zinga et al., 2008), but the causal agents have never been characterised molecularly.

In 2007 and 2008, leaves were collected in the central region of CAR and the south region of Chad from local cultivars of cassava exhibiting moderate to severe CMD symptoms (Table 1). Seven leaf samples collected both in CAR and Chad tested positive for the presence of begomoviruses by PCR, using a set of degenerate primers VD1863-A-CMG (5'-TCRTCAATGACGTTGTACCA-3') and C12D2391-A-CMG (5'-TTTCCAYCCVAACATTCARGG -3'). From two samples for each country (Table 1), four complete DNA-A genomes were cloned using the Phi29 DNA polymerase-based rolling circle amplification strategy and sequenced by Macrogen Inc. (Korea). Two sequences (EMBL-GenBank-DDBJ Accession Nos. HE814062 and HE814065), one per country, showed 96-97\% highest nucleotide identity (BLASTn, NCBI) with isolates of ACMV ([Nigeria:Ogoroco:1990] AJ427910; [Uganda:Severe:1997] AF126802), while the two other sequences (HE814063 and HE814064) showed 99\% highest nucleotide identity with isolates of EACMV-UG ([Uganda:Severe2:1997] AF126806; [Burkina Faso:Koubri:2008] FM877474 (Tiendrebeogo et al., 2009); [Democratic Republic of the Congo:Yangambi:2010] FN435281).

The new complete DNA-A genome sequences were aligned with representative sequences of CMGs using the MUSCLE alignment tool (using default settings) available in MEGA5. A maximum-likelihood (ML) phylogenetic tree (Fig. 1) was constructed from the full alignment using PHYML v3.0 with GTR+G4 selected as the best model of sequence evolution by RDP3. Phylogenetic analyses confirmed that the isolates of
CMGs reported here cluster with isolates of either ACMV or EACMV-UG. To our knowledge, this is the first report of the occurrence of the "Uganda variant" of CMD in Central African Republic and Chad, and needs to be taken into account for the regional management of cassava diseases and for regulatory phytosanitary bodies. This description seems to represent the northernmost extent of the CMD pandemic in Africa.

\section{Acknowledgements}

This study was supported by the MAEE (CORUS program), IAEA, CIRAD, the Embassy of France in Bangui (CAR), European Union (FEDER) and the Conseil Régional de La Réunion.

\section{References}

Akinbade SA, Hanna R, Nguenkam A, Njukwe E, Fotso A, Doumtsop A, Ngeve J, Tenku STN, Lava Kumar P, 2010. First report of the East African cassava mosaic virus-Uganda (EACMV-UG) infecting cassava (Manihot esculenta) in Cameroon. New Disease Reports [http://ndrs.org.uk] 21, 22. [http://dx.doi.org/10.5197/j.2044-0588.2010.021.022]

Neuenschwander P, Hughes J, Ogbe F, Ngatse JM, Legg JP, 2002. The occurrence of the Uganda Variant of East African cassava mosaic virus (EACMV-Ug) in western Democratic Republic of Congo and the Congo Republic defines the westernmost extent of the CMD pandemic in East/Central Africa. Plant Pathology 51, 384. [http://dx.doi.org/10.1046/j.1365-3059.2002.00698.x]

Patil BL, Fauquet CM, 2009. Cassava mosaic geminiviruses: actual knowledge and perspectives. Molecular Plant Pathology , 685-701. [http://dx.doi.org/10.1111/j.1364-3703.2009.00559.x]

Tadu G, Winter S, Gadelseed AMA, Dafalla GA, 2005. Association of East African cassava mosaic virus-Uganda (EACMV-UG) with cassava mosaic disease in Sudan. Plant Pathology 55, 287.

[http://dx.doi.org/10.1111/j.1365-3059.2005.01305.x]

Tiendrebeogo F, Lefeuvre P, Hoareau M, Traoré VSE, Barro N, Reynaud B, Traoré AS, Konaté G, Traoré O, Lett JM, 2009. Occurrence of East African cassava mosaic virus-Uganda (EACMV-UG) in Burkina Faso. Plant Pathology 58, 783.

[http://dx.doi.org/10.1111/j.1365-3059.2009.02110.x]

Zinga I, Nguimalet CR, Lakouetene DP, Konaté G, Kosh Komba E, Semballa S, 2008. Les effets de la mosaïque africaine du manioc en République Centrafricaine. [The impacts of African cassava mosaic in Central AfricanRepublic.] Geo-Eco-Trop 32, 47-60.

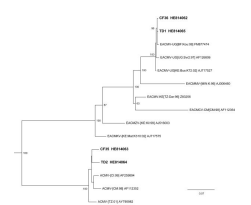

Figure 1

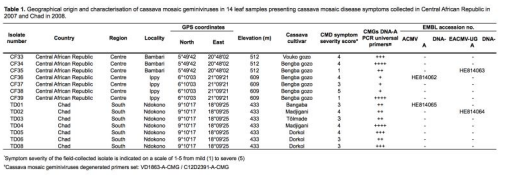

Figure 2

To cite this report: Zinga I, Harimalala M, De Bruyn A, Hoareau M, Mandakombo N, Semballa S, Reynaud B, Lefeuvre P, Lett JM, 2012. East African cassava mosaic virus-Uganda (EACMV-UG) and African cassava mosaic virus (ACMV) reported for the first time in Central African Republic and Chad. New Disease Reports 26, 17. [http://dx.doi.org/10.5197/j.2044-0588.2012.026.017]

(C) 2012 The Authors

This report was published on-line at www.ndrs.org.uk where high quality versions of the figures can be found. 